\title{
Orta Asya Taş Heykellerine Anadolu'dan İstisnai Bir Örnek: İnönü Taş Heykeli
}

\author{
Nurfeddin Kahraman ${ }^{*}$-Refik Arıkan ${ }^{* *}$-Mehmet Can Çetin ${ }^{* * *}$
}

(ORCID ID: 0000-0001-5561-7188 / 0000-0001-7813-8171 / 0000-0003-1791-6069)

\section{Makale Gönderim Tarihi}

18.12.2019

\section{Makale Kabul Tarihi}

28.12.2019

\section{Özet}

Ölüm, ait olduğu kültüre göre; hayatın sona erdiği ya da yeni bir hayatın başladığı, insana dair en önemli olaylardan biridir. İnsanlık tarihine bakıldığında ölüm daha çok yeni bir yaşama geçiş olarak kabul görmüş olup bu durum ölüyü defnetme şekillerinde de kendini göstermektedir. Türklerde görülen mezar odaları ve ölüler için dikilen heykeller bunun bir yansıması olarak kabul edilebilir. Bu açıdan mezarlar ve mezar taşları Türk Kültürü’nü somutlaştıran ve günümüze taşıyan kıymetli tarih hazinelerimizdendir.

Türkler, Orta Asya'da yaşadıkları zaman zarfında kendilerine ait bir medeniyet oluşturmuşlar ve göçlerle birlikte gittikleri farklı coğrafyalara bu tecrübelerini taşımışlardır. Her ne kadar değişen zaman, mekân ve inanç koşulları Orta Asya Türk Medeniyeti'ne dair uygulamaları farklılaştırsa da tarihî devamlılık açısından kültürel izleri takip etmek mümkün görünmektedir.

Eskişehir'in İnönü ilçesi merkez mezarlığında tespit ettiğimiz insan şekilli taş heykel, Orta Asya kültür ikliminin izlerini taşıması adına önemli bir yere sahipken; Türklerin Anadolu'ya yerleşme tarihleri açısından da ehemmiyetlidir. Anadolu'nun çeşitli yerlerinde insan şekilli taş heykel ya da balballara rastlanmasına rağmen; bunlar genelde taşa kazınarak yapılmışlardır. Ancak tespit ettiğimiz taş heykel form itibari ile Orta Asya örneklerine çok benzemektedir. Bunun yanında bulgumuzu istisnai hale getiren başka bir özellik de Kuzeybatı Anadolu'da bu konudaki ilk bulgu olmasıdır. Bunun yanında

\footnotetext{
* Prof. Dr., Bilecik Şeyh Edebali Üniversitesi, Fen-Edebiyat Fakültesi, Coğrafya Bölümü, nurfeddin.kahraman@bilecik.edu.tr.

** Doç. Dr., Bilecik Şeyh Edebali Üniversitesi, Fen-Edebiyat Fakültesi, Tarih Bölümü, refik.arikan@bilecik.edu.tr.

*** Yüksek Lisans Öğrencisi, Bilecik Şeyh Edebali Üniversitesi, Fen-Edebiyat Fakültesi, Tarih Bölümü, mccsanat26@gmail.com.
}

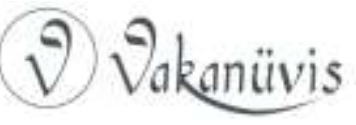


bölgede yürüttüğümüz saha incelemeleri ile bu tespiti güçlendirecek farklı örneklere de rastlanmıştır.

Anahtar Kelimeler: İnönü, İnsan Şekilli Taş Heykel, Balbal, Türk Kültürü

\title{
An Outstanding Example of Central Anatolia to Central Asian Stone Sculptures: İnönü Stone Statue
}

\begin{abstract}
Death depends on the culture to which it-belongs is one of the most important events of human being, where life ends or a new life begins. When we examine the history of humanity, death is accepted as a transition to a new life, and this situation also manifested in the form of deadly burials. The rooms of the tombs seen among the Turks and the sculptures erected for the measurements can be considered as a reflection of this. In this respect, tombs and grave stones are valuable for historical documents in terms of presentation of Turkish culture.

While living in Central Asia, the Turks created their own civilization and transferred these experiences to places where they traveled with migrations. Although changes in time, place and belief differentiate the practices of the Turkish civilization of Central Asia, it seems possible to follow cultural traces in terms of historical continuity.

While the human-shaped stone sculpture that we found in the central cemetery of İnönü district in Eskişehir occupies an important position in the name of bearing the traces of the cultural climate of Central Asia; it is also important for the history of colonization of the Turks in Anatolia. Despite the presence of human made stone sculptures or balbals in various parts of Anatolia, these are usually made by scraping the stone. However, the stone sculpture we have found is very similar to the examples of Central Asia. In addition to this, another feature that makes our results outstanding is the fact that this is the first discovery in Western Anatolia. In addition, examples were also found in field research conducted in the region to corroborate this conclusion.
\end{abstract}

Keywords: Inönü, Human Shaped Stone Sculpture, Balbal, Turkish Culture

\section{Giriş}

Türkler ölenin yerinin belli olması için kurgan inşa ederlerdi. Bunun yanında mezarların üzerine tümsek yapılması ve geniş daireler şeklinde taş yığılması da görülen uygulamalardandı. Yine mezarların üstüne 
balbal dikilerek mezarın yeri belirlenirdi. Balballar çok önemli dini mahiyette işaretler olup, bunlar kişinin savaşta öldürdüğü ya da öbür dünyada o kişiye hizmet edecek şahısları gösteren eserlerdi ${ }^{1}$. Ancak Balbal kişinin öldürdüğü düşmandan ziyade onu temsil eden anıt taşlar olarak ta belirtilmektedir².

Ölü gömme adetleri ile ilgili yapılmış olan heykellerin isimlendirilmesi konusu, Erken Türk Sanatı'nın terminolojik problemlerinden biridir. Orta Asya halkları arasında bu taşlar "Baba" olarak adlandırılırken; Orhun Yazıtları ile birlikte literatüre giren "Balbal" kelimesi, biçimsel benzerlik nedeni ile iki kavramın karıştırılmasına neden olmuştur. Baba olarak adlandırılan taş heykeller ölüyü temsilen mezarın batı ya da doğu tarafına dikilen ve genellikle üç boyut etkisi gösteren iyi işlenmiş taşlardır. Bunların sağ eli göğüs hizasında bir kap tutarken, sol el ise beldeki hançeri kavramaktadır ${ }^{3}$. Buna mukabil balbalların ise kişinin öldürdüğü şahısları temsilen dikildiğine dair bir kanaat oluşmuştur. Diğer taraftan Yılmaz ${ }^{4}$, bunların Çin imparatorunun kendisine öbür dünyada hizmet etmek üzere beraberinde gömüldükleri birebir insan ölçülerindeki heykellerle ilişkilendirilerek anlamlandırmaları gerektiğini ifade etmektedir.

\section{İnönü Taş Heykeli}

Taş heykel, Eskişehir'e bağlı İnönü ilçe merkezinde bulunan iki büyük mezarlıktan, şehrin doğusunda yer alan mezarlıkta, $20 \mathrm{~cm}$ 'si toprağa gömülü şekilde bulunmuştur. Taş heykel ilk olarak başka bir çalışma için saha araştırması ile görevlendirdiğimiz yüksek lisans öğrencimiz Mehmet Can Çetin tarafından tespit edilmiştir. Sonrasında yaptığımız incelemelerle bulgunun aydınlatılmasına çalışımıştır. Mezarlıktaki bu kültürel değerin varlığı bugüne kadar resmi makamlar ya da yörede yaşayanlarca fark edilmemiştir. Taş heykelin bulunduğu mezarlık, halk

\footnotetext{
1 İbrahim Kafesoğlu, Türk Milli Kültürü, Boğaziçi Yayınları, İstanbul 1996, s. 292-293, 327.

2 Mustafa Aksoy, Tarihin Sessiz Dili Damgalar, Yeni Ufuklar Derneği, İstanbul 2014, s. 146.

3 Anıl Yılmaz, "Gök Türk Heykelciliğinde Baba ve Balbal Kavramları Üzerine", Orta Asya'dan Anadolu'ya Türk Sanatı ve Kültürü (Prof. Nejat Diyarbekirli'ye Armağan), Ankara 2006, Yeni Türkiye Yayınları, s.111-112-115-126.

${ }^{4}$ Anıl Yılmaz, "Gök Türk Heykelciliğinde Baba ve Balbal Kavramları Üzerine", Orta Asya'dan Anadolu'ya Türk Sanatı ve Kültürü (Prof. Nejat Diyarbekirli'ye Armağan), s.119-124.
}

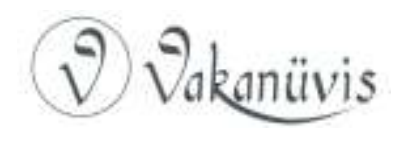


tarafından ${ }^{5}$ Germiyan Mezarlığı olarak da adlandırılan eski kabristanın hemen karşısında yer almakta ve aralarında bir yol bulunmaktadır.

Ek 1. İnönü Taş Heykeli.

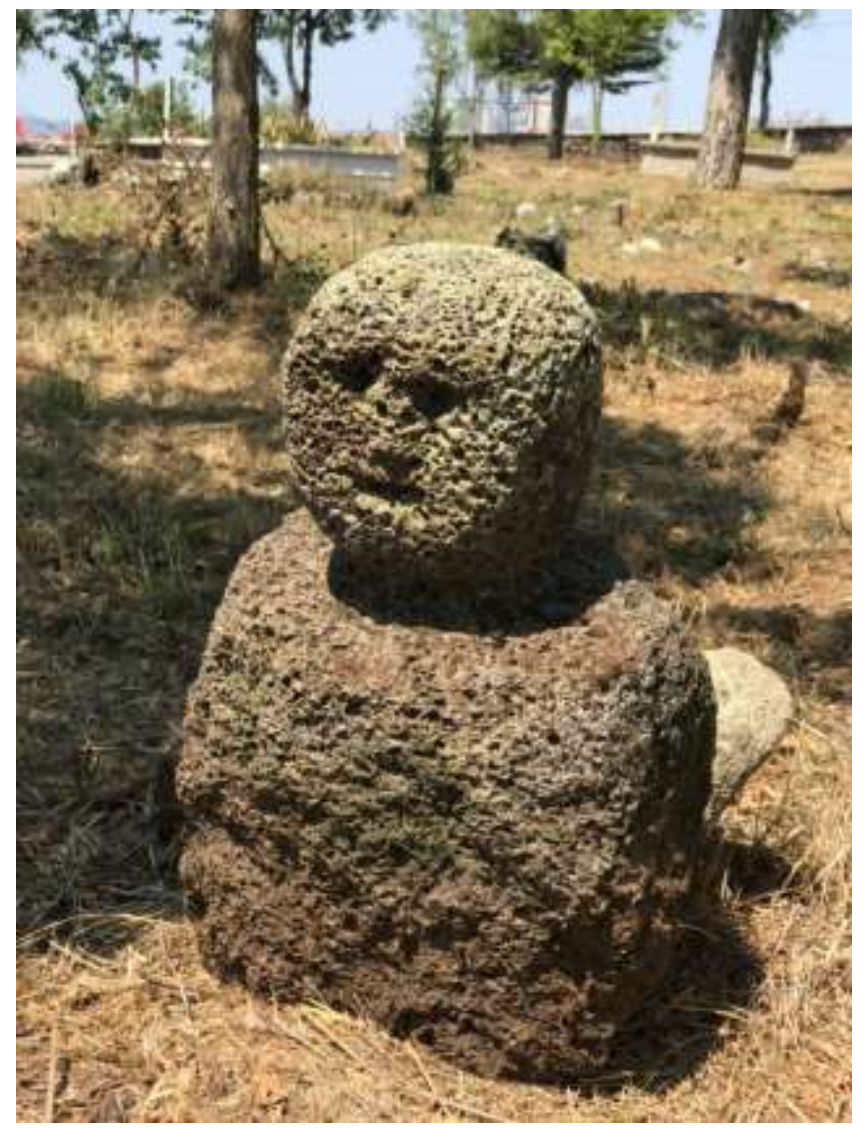

Kaynak: Mehmet Can Çetin Arşivi.

İlk olarak bulguya dair isimlendirme yapılmıştır. Evvelen, "Balbal" olarak adlandırılsa da; terminolojik probleme yukarıda dikkat çekildiği üzere bulgunun bir "Taş Heykel" olduğu kanaati hâsıl olmuştur.

Yapılan incelemelerde, başta sorulan soru; bu taş heykel bulunduğu yere mi aittir, yoksa başka bir yerden mi getirilmiştir? Bu bakımdan

${ }^{5}$ Ramazan Ayhan, 30.07.2018 tarihli mülakat, İnönü'de Kahvehane İşletmecisi.

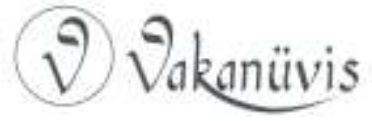


ortaya çıkarılan buluntu, öncelikle malzeme açısından incelenmiştir. Taş heykel, volkanik bir cüruf türü olan "Bazaltik" malzemeden mamuldür. Malzemenin kaynağı, mezarlığın $2 \mathrm{~km}$ kadar güneyinde yer alan ve Kuzdağı eteklerinden akmış olan bazaltik lavlardır. Yani malzeme yerli bir malzemedir. Diğer taraftan taş heykelin bulunduğu mezarlık içinde çok sayıda mezar taşı ve mezarlığı çevreleyen duvarlar da aynı malzeme kullanılarak yapılmıştır. Bu durum taş heykelin buraya ait olduğunu açıkça ortaya koymaktadır.

Saha araştırmalarımızın başlangıç evresinde, taş heykelin başka örneklerinin de bulunulabilmesi üzerine yoğunlaşıımış ancak bundan henüz bir sonuç alınamamıştır. Bir taraftan da araştırmamız taş heykelle ilişkilendirilebilecek başka deliller çerçevesinde yürütülmüştür. Aşağıda değinileceği üzere Erken Dönem Türk Kültürü ile ilgili bulgular, taş heykeli yapıp dikebilecek bir Türk topluluğunun bu bölgede yaşamış olduğunu açıkça ortaya koymaktadır.

\section{Taş Heykelin Fiziki Özellikleri}




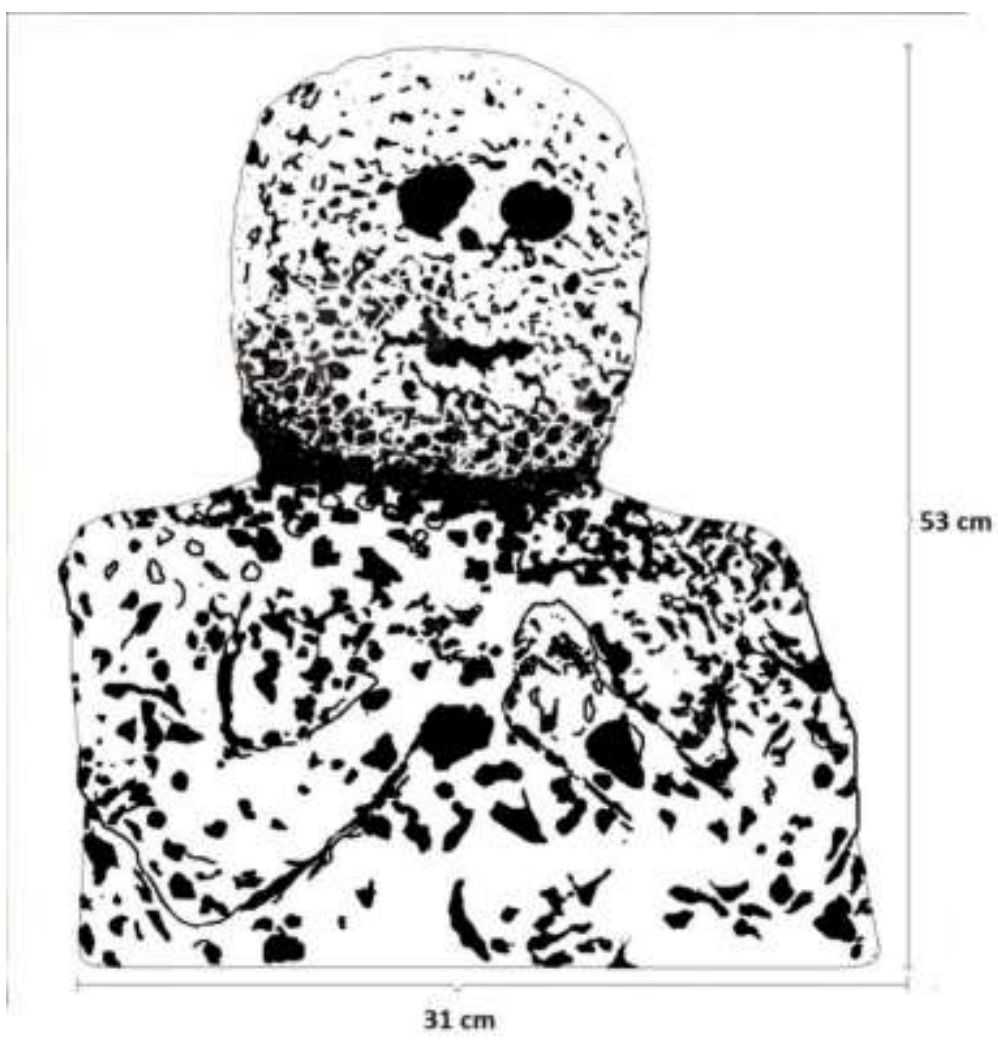

Şekil 1. Taş heykelin ölçüleri

Kaynak: Nurfeddin Kahraman.

İnönü mezarlığında tespit ettiğimiz taş heykel $53 \mathrm{~cm}$ boyunda ve 31 $\mathrm{cm}$ enindedir. İki kolunu göğsünde birleştirmiş şekilde yontulmuştur. Ancak bu kollar taşın yıpranması sebebiyle çok zor seçilebilmektedir.

Heykelin gövde boyu $34 \mathrm{~cm}$ ve başı ise $19 \mathrm{~cm}$ uzunluğundadır. Heykelin kalınlığı başta $13 \mathrm{~cm}$, omuzda $17 \mathrm{~cm}$ ve tabanda $14 \mathrm{~cm}$ 'dir. Toprağa gömülebilmesi için taban kısmı inceltilmiştir.

\section{Bölgenin Tarihi Coğrafyası}

İnönü, coğrafi konumu ve yol güzergâhları üzerinde olması sebebiyle Antik çağlardan günümüze farklı toplumların hayat ve göç sahalarından

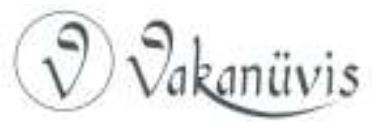


birisi olmuştur. Antik dönemde İnönü ve çevresi Basilika ${ }^{6}$ adıyla anılmıştır. Bölgenin Roma döneminde Frigya ya da Bithynia bölgelerinden hangisi içerisinde kaldığı tartışma konusudur. ${ }^{7}$ Umar, Bithynia bölgesi sınırları içerisinde gösterirken ${ }^{8}$, Sevin, Bythiynia sınırındaki küçük Frigya kenti olarak bahsetmektedir ${ }^{9}$. Buna sebep olarak bölgenin Bithynia ve Frigya arasında geçiş alanı olması gösterilebilir. Inönü'nün İznik (Nikea)-Malagina-Eskişehir (Dorylaion) gibi merkezi yerlerin ulaşım yolu üzerinde bulunması ve Malagina'nın Bizans'a ait askeri üs olarak kullanılması İnönü ve çevresinin ehemmiyetini de arttırmıştır. ${ }^{10}$ ilerleyen dönemlerde 1071 Malazgirt Zaferi Anadolu'nun Türkleşip İslamlaşmasında önemli bir milat olmuştur. illk olarak Anadolu'nun doğusunda Sultan Alparslan'ın emri ile Türk Beylikleri teşkil edilmiş; akabinde Süleyman Şah, Konya'dan İznik'e kadar olan bölgeyi ele geçirerek 1075 yılında başkenti İznik olan Türkiye Selçuklu Devleti'ni kurmuştur $^{11}$. İnönü ve çevresi muhtemeldir ki Süleyman Şah devrinde Türk hâkimiyetine girmiştir. Malazgirt zaferinin ardından bölgeye gelen Türkmen topluluklar, İnönü ve Bozüyük yöresinde; Döger, Çepni ${ }^{12}$, Yüreğir, Bayad ${ }^{13}, K^{\prime n} ı k^{14}$, Danişment, Taşçıahiler ${ }^{15}$, Sorguncuahiler ${ }^{16}$, Gündüzbey ${ }^{17}$, Savcıbey, Sırhoca, Yörük yayla ${ }^{18}$, Hoca Yadigâr ${ }^{19}$,

${ }^{6}$ William Mitchell Ramsay, Anadolu'nun Tarihi Coğrafyası, Çev: Mihri Pektaş, Milli Eğitim Basımevi, İstanbul, 1960, s. 229.

7 Vedat Turğut, Osmanlı Devletinin Kuruluş Coğrafyasında Vakıflar ve Şehirleşme (16.yy Bilecik ve Çevresi), Bilecik Şeyh Edebali Üniversitesi Yayınları, İstanbul, 2015, s. 14.

8 Bilge Umar, Bithynia, İnkılâp Kitapevi, İstanbul, 2004, s. 233-234.

${ }^{9}$ Veli Sevin, Anadolu'nun Tarihi Coğrafyası I, Türk Tarih Kurumu Yayınları, Ankara, 2016, s. 255.

10 John Haldon, Bizans Tarih Atlası, çev. Ali Özdamar, Kitap Yayınevi, İstanbul, 2007, s. 31.

11 Osman Turan, Selçuklular Zamanında Türkiye, Ötüken Neşriyat, İstanbul, 2016, s. 84.

12 Kumralbaba, Kamuran Gazi, Aksutekke, Çepni, Yüreğir köyleri ve Dodurga Beldesi Bilecik İlinin Bozüyük İlçesi'ne bağlıdır.

13 Faruk Sümer, Oğuzlar, Türk Dünyası Araştırmaları Vakfı, İstanbul, 2016, s. 397-399407-412.

14 Kınık köyü Bilecik merkeze bağlıdır.

${ }^{15}$ Bayat ve Taşçıahiler köyü Bilecik İlinin Gölpazarı İlçesi'ne bağlı köylerdir.

${ }^{16}$ Danişment ve Sorguncuahiler köyü Bilecik İlinin Yenipazar İlçesi'ne bağı köylerdir.

17 Gündüzbey, Savcıbey ve Sırhoca köyleri Bilecik İlinin Söğüt İlçesi'ne bağlı köylerdir.

18 Yörükyayla, Hocayadigar köyleri Eskişehir İnönü İlçesi'ne bağlı köylerdir.

${ }^{19}$ Rudi Paul Lindner, Osmanlı Tarih Öncesi, Kitap Yayınevi, İstanbul, 2014, s.82: Eskişehir İnönü İlçesi'ne bağlı olan Hocayadigar köyünün günümüzdeki adı Aşağıkuzfındık olarak

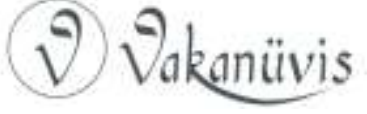


Aksutekke, Kamuran Tekke ${ }^{20}$, Kumral Baba ${ }^{21}$, Göktepe, Ahiler ${ }^{22}$, Kayı ${ }^{23}$ ve Dodurga gibi yerleşim birimlerinin ortaya çıkmasında etkili olmuştur. Bahsi geçen mekânlar, isimlerini Oğuz boylarından ve bölgedeki Türk yerleşiminde etkili olan kişi ve kurumlardan almışlardır. Eskişehir'in Inönü İlçesi'nin Osmanlı Beyliği'nin kuruluşundan evvel bir Türk yerleşimi olduğu aşikârdır. Özellikle Turğut'un Osmanlı kuruluş coğrafyasında vakıflar üzerine yaptığı araştırmalarda İnönü Beyi olduğu düşünülen İdris Battal Bey'e ait kadimden vakı ${ }^{24}$ bulunduğu belirtilmektedir ${ }^{25}$. Bunun yanı sıra İnönü şehir merkezinde bulunan 1369-70 tarihli Alâeddin Camisi'nin Osmanlı kuruluş devrinde yörede bulunan yoğun Türk nüfusu sebebiyle inşa edildiği muhtemeldir ${ }^{26}$.

\section{Bölgede Eski Türk Kültür ve İnançlarına Dair Bulgular}

Yukarıda belirtildiği üzere yapılan saha araştırmalarında taş heykelin başka örnekleri aranmış ancak bulunamamıştır. Bunun üzerine araştırma taş heykel ve onu yapan toplumla ilişkilendirilebilecek başka veriler üzerinde yoğunlaştırılmıştır.

Bölgede erken Türk varlığına işaret eden delillerden bir tanesi de Göktepe Kurgan alanıdır ${ }^{27}$. Kurgan, yığın veya tepe gibi anlamlar

değiştirilmiştir. İnönü şehir merkezinde bulunan Alâeddin Cami'sinin Arapça kitabesinde "Hayır ve hasenat sahibi Sultan Ali oğlu Yadigâr Hoca bunu yaptırdı H.77l/1369-70" tarihli yazıttan anlaşılacağı üzere Hocayadigar adı Osmanlı Kuruluş devrine tekabül etmektedir.

20 Kamuran Gazi Ertuğrul Gazinin silah arkadaşı olarak anılır. Köyde türbesi bulunmaktadır. Günümüzde Bilecik'in Bozüyük İlçesi'ne bağı olan Kamurantekke Köyü'nün adı Metristepedir.

${ }^{21}$ Osmangazi zamanında Kumral Abdal'a vakıf olarak verilen Bilecik'in Bozüyük İlçesi'ne bağlı olan Kumralbaba Köyü'nün günümüzdeki adı Kovalıcadır.

${ }^{22}$ Göktepe ve Ahiler Köyü Eskişehir Sivrihisar İlçesi'ne bağlı köylerdir.

${ }^{23}$ Kayı Köyü Eskişehir Mihalıçcık illçesi'ne bağlı köydür.

${ }^{24}$ Bu İbare vakfın Osman Bey ya da daha önceki döneme gittiği hallerde kullanılmaktadır.

${ }^{25}$ Vedat Turğut, Osmanlı Devletinin Kuruluş Coğrafyasında Vakıflar ve Şehirleşme (16.yy Bilecik ve Çevresi), s.61.

${ }^{26}$ Refik Arıkan-Mehmet Can Çetin, "Bilecik Çevresindeki Ahi Zaviyeleri ve Teşkilatının Osmanlı Devletinin Kuruluşundaki Rolleri", Uluslararası 4. Ahilik Sempozyumu Bildiri Kitabı, Nehir Matbaacılık, Kırşehir, 2018, s. 640-641.

27 İnönü Ahalisinden 1962 doğumlu Ramazan Ayhan ile 30.07.2018 tarihinde yapmış olduğumuz sözlü mülakatta İnönü Göktepe'de Yörük Mezarı olarak adlandırılan mezarlar olduğu mezarlığın bulunduğu alanda daha önceden yufka hayrı yapıldığını belirtmiştir.

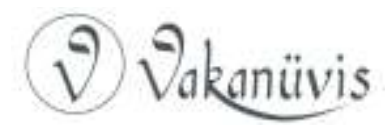


içermesine rağmen, mezarın kendisinden ziyade korunacak alanı vurgulamaktadır. Nitekim Kurgan adı Türkçe "korumak" fiilinden gelmektedir ${ }^{28}$. Bu nedenle bu tip mezarların kurganlı mezar olarak adlandırımaları daha doğrudur. Bu bakımdan kurganı belirleyen temel unsur, üzerinde toprak ya da taş yığılı olmasıdır. Diğer yandan bir mezarın kurgan olarak nitelendirilmesi için altında mutlaka mezar odası olması gerekmez. Oda yerine ölünün gömüldüğü bir çukur da olabilir ${ }^{29}$. Diğer taraftan kurgan kelimesi mezarın üstündeki yığın tepe anlamına da gelmektedir ${ }^{30}$. Göktepe'de bulunan kurganlarda kaçak kazılar yapıldığı görülmüştür. Kazılardan çıkan hafriyat malzemesine göre de bu kurganlarda mezar odası bulunmadığı; yukarıda ifade edildiği gibi sadece mezar çukuru olduğu anlaşılmıştır. Bu tepeye verilen isimden ve kurgan tipi mezarlardan yola çıkarak Göktepe'nin bir ayin alanı, kutsal bir mekân olduğu söylenebilir.

Göktepe'de bulunan mezar alanı "Bozkır" tipi mezar olarak da değerlendirilebilir. Nitekim Türklerde mezarlar Tümsekli ve Bozkır mezarlar olarak ikiye ayrılmaktaydı. Tümsekli mezarlar yüksek tepelerden ziyade vadilere yapılmışır. Bozkır mezarlar ise Tümsekli mezarlara göre daha yüksek tepelerde yer almaktadır ${ }^{31}$. Bu bilgiden hareketle Göktepe'nin zirve kesimindeki kurgan alanının, tipik bir Bozkır mezarı olduğu iddia edilebilir.

Bölgede Türklere ait bir takım simgeler de burada Orta Asya kültürünün canlılığına işaret eder. Koçbaşı ya da boynuzu Türklerde çok önemli yere sahiptir. Kurganlarda ölü ve eşyaları ile birlikte at, koç gibi hayvanlara dair kalıntılar da sıklıkla görülmektedir. Bu hayvanları ölü ile birlikte kurban edilerek gömüldükleri eski Türk inançlarında yer almaktadır. Nitekim gökyüzü için at kurban edilirken; toprak için de koç

28 Ahmet Taşağıl, Kök Tengri'nin Çocukları, Bilge Kültür Sanat Yayınları, İstanbul, 2014, s. 78.

${ }^{29}$ Yaşar Çoruhlu, "Kurgan ve Balık (Ordu-Balık) Terimleri (İsimleri) Üzerine Düşünceler", Orta Asya'dan Anadolu'ya Türk Sanatı ve Kültürü (Prof. Nejat Diyarbekirli'ye Armağan), Ankara 2006, Yeni Türkiye Yayınları, s. 103-108-110-109.

30 Yaşar Çoruhlu, Eski Türklerin Kutsal Mezarları Kurganlar, Ötüken Yayınevi, İstanbul 2016, s. 26-27.

31 Bahaeddin Ögel, Islamiyet'ten Önce Türk Kültür Tarihi(Orta Asya Kaynak ve Buluntularına Göre), Türk Tarih Kurumu Yayınları, İstanbul, 2014, s. 137-139.

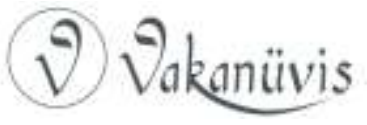


kurban edilmiştir ${ }^{32}$. Texier eserinde, İnönü'de türkü söyleyerek tarlaya çalışmaya giden başlarında boynuz taşıyan kadınlar gördüğünü belirtmiştir. ${ }^{33}$ Inanışın bir devamı olarak görülebilecek bu tespitte tarlaya gidenlerin bereket sembolü olarak boynuzları taşıdıkları görülmektedir.

Aynı coğrafyada bulunması sebebiyle Bilecik şehir merkezinde tespit edilen bir mezar da bölgede yaşayan halkın dini inançlarının belirlenmesi adına önemlidir. Bilecik Orhan Gazi İmareti Arkeolojik kazı çalışmaları esnasında tespit edilen mezarın içerisinde dağ keçisi iskeletine rastlanmıştır. Mezarın yapısı ve içerisinde bulunan keçi iskeleti İslami geleneklere uygun bir mezar olmadığını göstermektedir. Buradan hareketle bu mezarın "heterodoks" etki taşıdığını söylemek mümkündür ${ }^{34}$.

Türk hayvan üslubunun karakteristik özelliklerinden birisi olarak karşımıza çıkan koçboynuzuna saha çalışmaları sırasında İnönü şehir merkezinde bulunan Alâeddin Caminin Arapça kitabesinde rastlanılmıştır: "Hayır ve hasenat sahibi Sultan Ali oğlu Yadigâr Hoca bunu yaptırdı" ibaresi ve kitabe üzerine işlenmiş "koçboynuzu" bulunmaktadır. Lindner'in bu kitabe hakkında "inönü'deki eski camide Hoca Yadigâr b. Sultan Ali adını taşıyan H.77ı/1369-70 tarihli bir yazıt bulunur: Bu Sultan Ali Germiyan beylerinden biri olabilir" ${ }^{35}$ şeklinde tespiti bulunmaktadır.

Bulduğumuz taş heykelle ilişkilendirilecek örneklerden bir tanesi de Söğüt'ün Borcak Köyü’nde bulunan İsa Sofi Türbesi'dir. Erken dönem Osmanlı eseri olma ihtimali yüksek olan bu türbe tezyinatı ile dikkat çekmektedir. Yapmış olduğumuz saha incelemeleri sırasında, Bilecik'in Söğüt İlçesi'ne bağlı Borcak Köyü'nde köye göre yüksek bir konumda bulunan İsa Sofi Türbesi'nin iç duvarlarında kök boya ile yapılmış ve "Eski

\footnotetext{
32 Mustafa Aksoy, Tarihin Sessiz Dili Damgalar, Yeni Ufuklar Derneği, İstanbul, 2014, s. 180.

33 Kudret Emiroğlu, Gündelik Hayatımızın Tarihi, İş Bankası Kültür Yayınları, İstanbul, 2007, s. 15.

${ }^{34}$ Abdullah Deveci-Erol Altınsapan, "Bilecik Orhangazi İmareti Kazısında Bulunan Dağ Keçisi Gömütlü Mezar", Akademik Sosyal Araştırmalar Dergisi, 27, s.4.

${ }^{35}$ Rudi Paul Lindner, Osmanlı Tarih Öncesi, s.82.
}

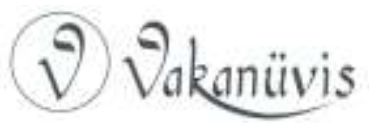


Türk Kozmolojisini" içeren çizimler olduğunu tespit edilmiştir ${ }^{36}$. İslami kimliği ile toplumda ön planda olan bir kişinin anıt mezarının Gök Tanrı inancına ait figürle bezenmiş olması ${ }^{37}$, Orta Asya'dan taşınan kültür ikliminin bu bölgede uzun süre devam ettirildiğini göstermesi açısından ehemmiyeti haizdir.

İnönü Mezarlığı'nda tespit ettiğimiz taş heykelin neden burada olduğunun ya da buraya ait olduğunun kanıtlarından bir tanesi de aynı çevrede bulduğumuz "dört-yön tamgası"dır. Eski Türkler'de tamga, tamka veya damga şekillerinde yazılan kelime, "el ile yapılan motif" anlamına gelmektedir ${ }^{38}$. Bu tamgalar, bir boyu simgelediği gibi, yapanların hangi millete ait olduğunu da gösterirler. İnönü'de Kuzdağı'nın eteğinde Martlıbaşı mevkiinde bulunan Roma devrinden kalma Martlı suyunun ${ }^{39}$ künkleri üzerine kazınmış bir şekilde Türklerin dört-yön tamgası bulunmaktadır. Benzer örnekler bu bölgede yer alan diğer eserlerde de görülebilmektedir.

Bölgede Türklere ait tamgaların izini sürmek için yapmış olduğumuz araştırmalar neticesinde İnönü Alâeddin Cami (1369) kitabesinin alt kısmında ve Bozüyük Kasımpaşa Camii (1528) minaresinde Türk kültüründe "Oz Tamgası" ${ }^{40}$ olarak adlandırılan tamgalar tespit

\footnotetext{
${ }^{36}$ Nurfettin Kahraman, Refik Arıkan ve Mehmet Can Çetin, "Isa Sofi Türbesi: Tezyinatı ve Türklerin İslamlaşma Süreci Açısından Değerlendirilmesi", Türk Kültürü Incelemeleri Dergisi, 41, (2019), s. 121-154.

37 Yaşar Çoruhlu, Eski Türklerin Kutsal Mezarları Kurganlar, Ötüken Yayınları, İstanbul 2016, s. 391: Türbedeki bezemelerde ağırlıklı olarak kırmızı renk kullanılmıştır. Kırmızı rengin tercih edilmesi öteki dünyada diriliş ile ilgili olabilir ki kırmızı hayat veren kanın rengidir. Diğer taraftan kırmızı rengin kötü ruhlardan koruduğuna da inanılır:

38 Yusuf Halaçoğlu, "Damga", i̇lam Ansiklopedisi, VIII, (1993), s.454.

${ }^{39}$ Cahit Kardeş, 01.08.2018 tarihli mülakat, İnönü, Emekli öğretmen: Yerel Rivayette “Milattan sonra 500'lü yıllarda İnönü ilçesi, yapılan bir kiliseden dolayı Bazilika olarak adlandırılmış. Bu sırada Bazilika'nın tekfuru Yuhanman, Kuz Dağı́nda yapılan avlara katılıyordu. Burada bulunan bir su kaynağını keşfeden tekfur, suyun çıkış noktasına bir mahzen yaptırdı. Daha sonra suyu toprak künkler ile İnönü Kalesi'ne kadar ulaştıran Yuhanman, bir tören düzenledi. Törende ise kızı Marthaya'nın ismini suya verdi. Dilden dile gelen Marthaya Suyu, Martlı Suyu olarak kaldı."şeklinde mülahazalarını paylaşmıştır; Bilge Umar, Türkiye'deki Tarihsel Adlar, İnkılâp Kitabevi, İstanbul 1993 s. 156: Nitekim İnönü Bizans zamanında Bazilika adıyla bilinmektedir:

${ }^{40}$ Mustafa Aksoy-Ayfer Zencirkaya, "Arapgir'de Bazı Maddi Kültür Eserleri ve Damgalar", Türk Dünyası Tarih Kültür Dergisi, (2017), s.44
}

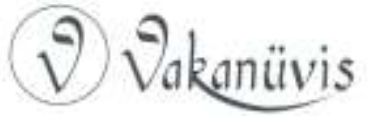


edilmiştir. Böylece Türklerin tamgaları mimari öğelere işleyerek kültürlerini her dönem devam ettirdikleri görülmektedir.

Diğer taraftan İnönü' de bulunan mezarlıklarda yer alan bazı mezar taşlarının formları da eski kültürün izlerini taşımaktadır. Orta Asya mezar sanatının yansıması olarak soyutlaşmış şahideli (başlıklı) mezar taşları dikkat çekmektedir. İnönü'nün batısında yer alan şehir mezarlığında görülen bu örnek kültürel devamlılığın bir başka delilidir.

Daha öncede belirtildiği üzere çalışmamıza konu olan bulgu Anadolu'daki ilk örnek olarak ifade edilebilir. Bununla birlikte insan suretli mezar taşı geleneği eski bir Türk geleneği olarak Anadolu'da yaşamış olup buna dair pek çok örnek bulunmaktadır. Ancak zikredilen bu bulgular bir heykelden ziyade taşa kazınmış ya da kabartılmış rölyef formundadır. Denizli'de her iki şekilde de mezar taşları tespit edilmiştir ${ }^{41}$. Benzer örneklere Anadolu'nun farklı noktalarında rastlanmaktadır. Yozgat merkez Çalatı Köyü'nde yer alan ve 1939 tarihinde vefat eden Hasan Baldemir'e ait mezar taşı bu geleneğin yakın zamanlara kadar canlı olduğunu göstermektedir ${ }^{42}$. Benzer örnekler Ardahan çevresinde de bulunmaktadır. Burada bulunan örneklerde yüz formu olmasa da kadın ya da erkek olduğuna dair bir üslup takip edilmektedir. Ancak bu örnekler klasik balbal ya da taş heykel formundan uzaklaşmışlardır ${ }^{43}$. Nitekim Osmanlı Mezar taşları da insan yüzüne dair izler içermese de başlıkları ve genel formları itibari ile kadın ile erkek için ayrı şekillere sahiptirler. Buna dair güzel örneklerden bir tanesi de Bilecik'te Şeyh Edebalı Türbesi yakınlarında bulunmaktadır ${ }^{44}$.

Bir mezar geleneği olarak balballar ve taş heykeller, Türkistan'dan Anadolu ve Avrupa'ya kadar Türk hâkimiyetinin ve kültürünün yayıldığı yerlerde görülmektedir. Formu ait olduğu coğrafyaya göre değişiklik gösterse de Türk izlerini yansıtması adına son derece önemli tarihi kültür

\footnotetext{
41 Türk Bilimi, "Denizli-Türklerde Mezar Taşları Balbal" , http://www.turkbilimi.com/denizli-balbal/, [Erişim Tarihi: 06.11.2019]: Bu tespitler yerel araştırmacı Ümit Şıracı tarafından yapılmıştır.

42 Ülkem Yaz, "Yozgat Merkez Çalatlı Köyünde Bulunan Balbal Formunda Mezar Taşları", Bozok Sempozyum Bildirileri, IV, Yozgat, (2016), s. 390-398.

43 Yunus Berkli, "Ardahan-Çıldır Çevresinde Heykel Biçimli Mezar Taşlarının Türk Sanatındaki Yeri ve Önemi", Sanat Dergisi, 9, (2006), s. 174-186.

44 İlhami Yurdakul, Refik Arıkan ve Halim Demiryürek, Şehrin Hafızası Bilecik Mezar Taşları ve Kitabeleri, Babıali Kültür Yayıncılığı, İstanbul, 2019, s.213.
}

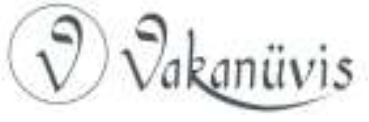


varlıklarıdır. Üsküp'te ve Üsküp yakınlarındaki Kumanova'da bulunan insan şekilli taş heykeller buna dair ilginç örneklerdendir ve bunlar Avrupa Türk varlığının en eski kayıtlarından birisi olup muhtemelen İskitlere aittirler ${ }^{45}$.

İslamlaşma ile heykel sanatı her ne kadar mezar taşlarından uzaklaşmış gibi görünse de Osmanlı mezar taşları aynı izleri taşımaktadır. Nitekim Osmanlı mezar taşı formlarına bakıldığında; yüz hatları ve vücut uzuvları kalkmış olsa da özellikle yazılı taşlarda kadın erkek ayrımı, meslek ya da mensup olunan tarikatlar kolayca ayırt edilebilmektedir. Bu manada Osmanlı mezar taşları ile Orta Asya taş heykelleri arasında bir bağ kurmak mümkündür.

\section{Sonuç}

Türkler Orta Asya kültür ve medeniyetini göçlerle birlikte gittikleri yerlere de taşımışlardır. Diğer taraftan karşılaştıkları yeni inanç sistemleri ile göçler sırasında geçilen ve yeni yerleşilen bölgelerin kültürü de Türklerin hayat tarzlarını etkilemiştir.

Günümüzde elde edilen bulgular, bu mirası bırakan toplumun yerleştikleri bölgeye gelişleri, inançları vs. hakkında çıkarım yapmaya imkân tanımaktadır. Ankara-Güdül'de bulunan kaya yazıt ve resimlerinden hareketle Türklerin 1071 öncesi Anadolu'ya yerleştiklerine dair iddialar ortaya atılmıştır ${ }^{46}$.

İnönü'de tespit ettiğimiz insan suretli taş heykel ve yukarıda ortaya koyduğumuz diğer deliller Türklerin Anadolu'ya yerleşim tarihleri ile ilgili yeni fikirler verebilir. Diğer taraftan bu durum Orta Asya KültürMedeniyetinin kuzeybatı Anadolu'da çok güçlü bir şekilde muhafaza edildiğini göstermektedir.

Küreselleşme tehdidi altında her geçen gün örselenen kültür kodlarımızın ne kadar köklü ve sağlam olduğunun da göstergesidir, bu bulgular. Örneklerle de görüldüğü üzere 16. yüzyılda kadınların bereket inancı olarak koçboynuzu taşımaları gibi tecrübeler araştırmalarımıza

\footnotetext{
${ }^{45}$ Mustafa Aksoy, "Makedonya'da Balballar, İskitler-Türkler”, Türk Dünyası Tarih Kültür Dergisi, (2011), s. 10-11.

${ }^{46}$ Youtube, Servet Somuncuoğlu, "Taştaki Türkler-Damgaların Göçü” https://www.youtube.com/watch?v=mSiz8zYnULg., [Erişim Tarihi: 01.10.2019]
}

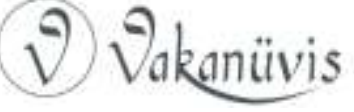


konu olan Bilecik ve çevresi gibi dar bir coğrafyada Türk Kültürü’nün ne kadar canlı olduğunu göstermektedir. Bu bağlamda çalışmaya konu olan taş heykel Anadolu'da bu formda ilk örneklerden olması noktasında önemi haiz olduğu gibi Türklerin Anadolu'da ne kadar zamandır var olduklarına dair tartışmalara da katkı sağlayacaktır. Her şeye rağmen bu tür örnekler Türkistan'da neşvünemâ bulan Türk Medeniyeti'nin yayıldığı her alanda varlığını koruduğunu göstermekte ve bu sonuç bıraktığı bu mirastan da anlaşılmaktadır. 


\section{Kaynakça}

Aksoy, Mustafa, "Makedonya'da Balballar, İskitler-Türkler", Türk Dünyası Tarih Kültür Dergisi, (2011), s. 9-13.

Aksoy, Mustafa, Tarihin Sessiz Dili Damgalar, Yeni Ufuklar Derneği Yayını, İstanbul 2014,

Aksoy, Mustafa-Zencirkaya, Ayfer, “Arapgir'de Bazı Maddi Kültür Eserleri ve Damgalar”, Türk Dünyası Tarih Kültür Dergisi, ( 2017), s. 39-45.

Arıkan, Refik-Çetin, Mehmet Can, "Bilecik Çevresindeki Ahi Zaviyeleri ve Teşkilatının Osmanlı Devletinin Kuruluşundaki Rolleri", Uluslararası IV. Ahilik Sempozyumu, (27-29 Eylül 2018), Nehir Matbaacılık, Kırşehir 2019, s.633-647.

Ayhan, Ramazan, 30.07.2018 (Kişisel Görüşme), İnönü.

Berkli, Yunus, "Ardahan-Çıldır Çevresinde Heykel Biçimli Mezar Taşlarının Türk Sanatındaki Yeri ve Önemi”, Sanat Dergisi, 9, (2006), s. 174-186.

Çetin, Mehmet Can, Nefs-i Karadona Nam-ı Diğer Bozüyük (Cami ve Türbeler), Tunç Yayıncılık, İstanbul 2018,

Çoruhlu, Yaşar, "Kurgan ve Balık (Ordu-Balık) Terimleri (İsimleri) Üzerine Düşünceler", Orta Asya'dan Anadolu'ya Türk Sanatı ve Kültürü (Prof. Nejat Diyarbekirli'ye Armağan), Yeni Türkiye Yayınları, Ankara 2006, s.103-110.

Çoruhlu, Yaşar, Eski Türklerin Kutsal Mezarları Kurganlar, Ötüken Yayınları, İstanbul 2016.

Deveci, Abdullah-Altınsapan Erol, "Bilecik Orhangazi İmareti Kazısında Bulunan Dağ Keçisi Gömütlü Mezar", Akademik Sosyal Araştırmalar Dergisi, 27, (2016), s.1-17.

Emiroğlu, Kudret, Gündelik Hayatımızın Tarihi, İş Bankası Kültür Yayınları, İstanbul 2017.

Haldon, John, Bizans Tarih Atlası, çev. Ali Özdamar, Kitap Yayınevi, İstanbul 2007.

Halaçoğlu, Yusuf, "Damga", İslam Asiklopedisi, VIII, (1993), s. 454-455.

Kafesoğlu, İbrahim, Türk Milli Kültürü, Boğaziçi Yayınları, İstanbul 1996.

Lindner, Paul Rudi, Osmanlı Tarih Öncesi, çev. Ayda Arel, Kitap Yayınevi, İstanbul 2014,

Kahraman, Nurfettin, Arıkan, Refik ve Çetin, Mehmet Can, "İsa Sofi Türbesi: Tezyinatı ve Türklerin İslamlaşma Süreci Açısından Değerlendirilmesi”, Türk Kültürü İncelemeleri Dergisi, 41, (2019), s. 124-154.

Kardeş, Cahit, 01.08.2018 ( Kişisel Görüşme), İnönü.

Ögel, Bahaeddin, İslamiyet'ten Önce Türk Kültür Tarihi (Orta Asya Kaynak ve Buluntularına göre), T.T.K Yayınları, İstanbul 2014.

Ramsay, M.W., Anadolu'nun Tarihi Coğrafyası, Milli Eğitim Basımevi, İstanbul 1960.

Sümer, Faruk, Oğuzlar, Türk Dünyası Araştırmaları Vakfı, İstanbul 2016. 
Sevin, Veli, Anadolu’nun Tarihi Coğrafyası I, T.T.K Yayınları, Ankara 2016.

Turğut, Vedat, Osmanlı Devleti'nin Kuruluş Coğrafyasında Vakıflar ve Şehirleşme (16.yy.Bilecik ve Çevresi), Bilecik Şeyh Edebali Üniversitesi Yayınları, İstanbul 2015.

Turan, Osman, Selçuklular Zamanında Türkiye, Ötüken Neşriyat, İstanbul 2016.

Taşağıl, Ahmet (2014), Kök Tengri'nin Çocukları, Bilge Kültür Sanat Yayınları, İstanbul 2014.

Umar, Bilge, Bithynia, İnkılâp Kitabevi, İstanbul 2004.

Umar, Bilge, Türkiye'deki Tarihsel Adlar, İnkılâp Kitabevi, İstanbul 1993.

Yaz, Ülkem, "Yozgat Merkez Çalatlı Köyünde Bulunan Balbal Formunda Mezar Taşları", Bozok Sempozyum Bildirileri, C 4, (2016), s.390-398.

Yılmaz, Anıl, "Gök Türk Heykelciliğinde Baba ve Balbal Kavramları Üzerine", Orta Asya'dan Anadolu'ya Türk Sanatı ve Kültürü (Prof. Nejat Diyarbekirli'ye Armağan), Yeni Türkiye Yayınları, Ankara 2006, s. 111-126.

Yurdakul, İlhami, Arıkan Refik, Demiryürek Halim, Şehrin Hafızası Bilecik Mezar Taşları ve Kitabeleri, Babıali Kültür Yayıncılığı, İstanbul 2019.

Elektronik Kaynaklar

Türk Bilimi, "Denizli-Türklerde Mezar Taşları Balbal" , http://www.turkbilimi.com/denizli-balbal/, [Erişim Tarihi: 06.11.2019]

Youtube, Servet Somuncuoğlu, "Taştaki Türkler-Damgaların Göçü" https://www.youtube.com/watch?v=mSiz8zYnULg., [Erişim Tarihi: 01.10.2019] 


\section{Ekler}

Ek 2: İnönü’nü batı mezarlığında şahideli soyutlaşmış mezar taşı örneği.

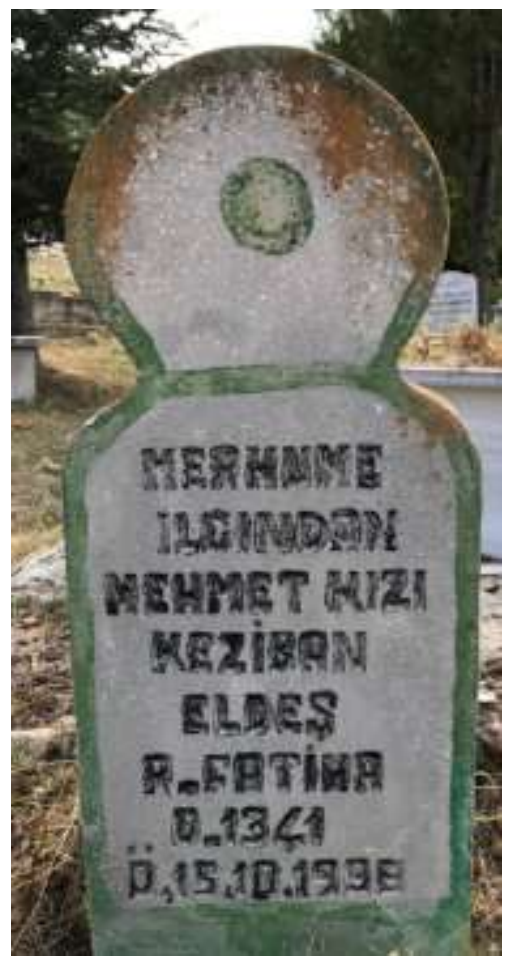

Kaynak: Mehmet Can Çetin. 
EK 3: İnönü Alâeddin Camii Kitabesinde yer alan koç boynuzu figürü.

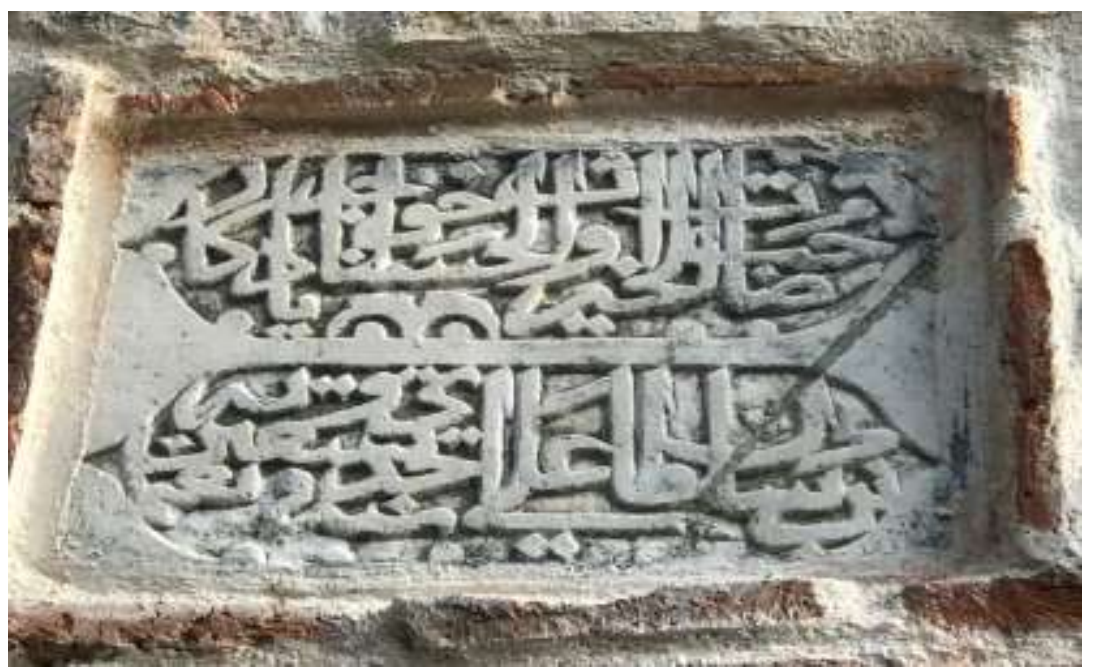

Kaynak: Mehmet Can Çetin.

Ek 4: İnönü Alâeddin Camii Kitabesi'nin yan tarafında "çarkıfelek" figürü.

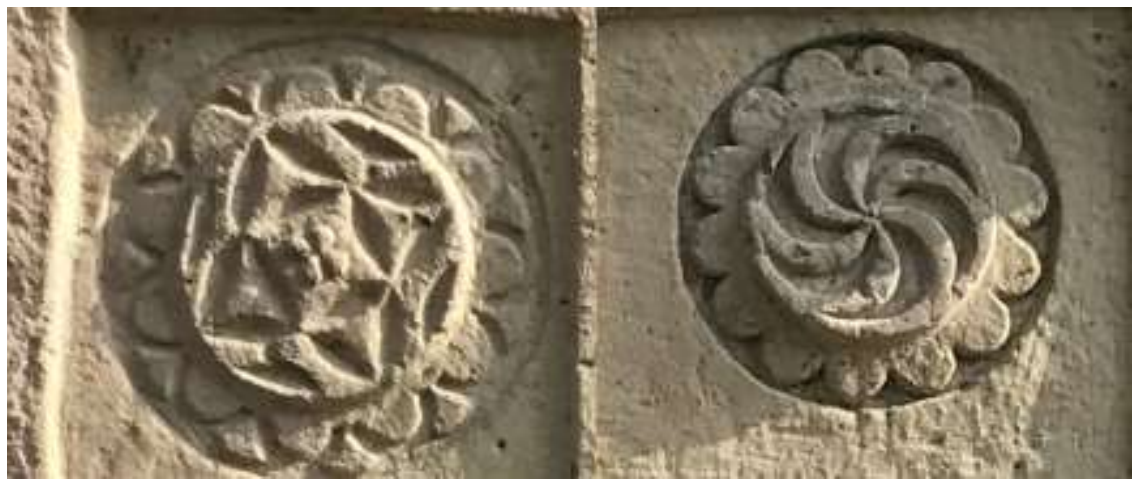

Kaynak: Refik Arıkan.

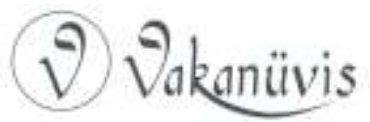


Ek 5: Martlı suyu taş mahzeninde yer alan "dört-yön tamgası".

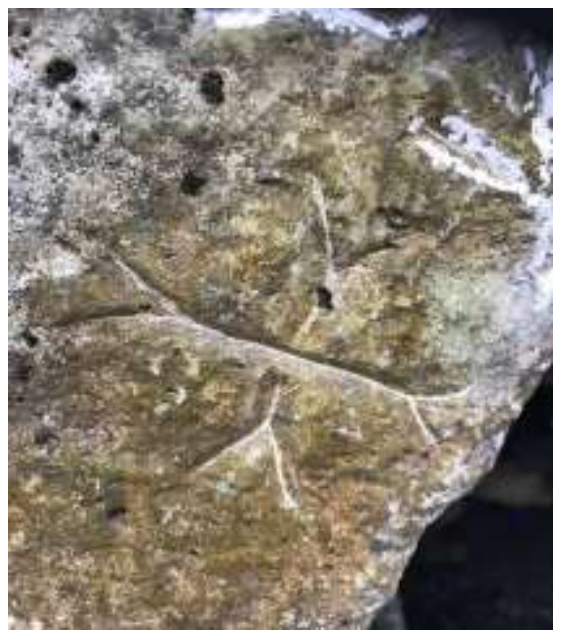

Kaynak: Refik Arıkan.

Ek 6: Göktepe Kurgan Alanı.

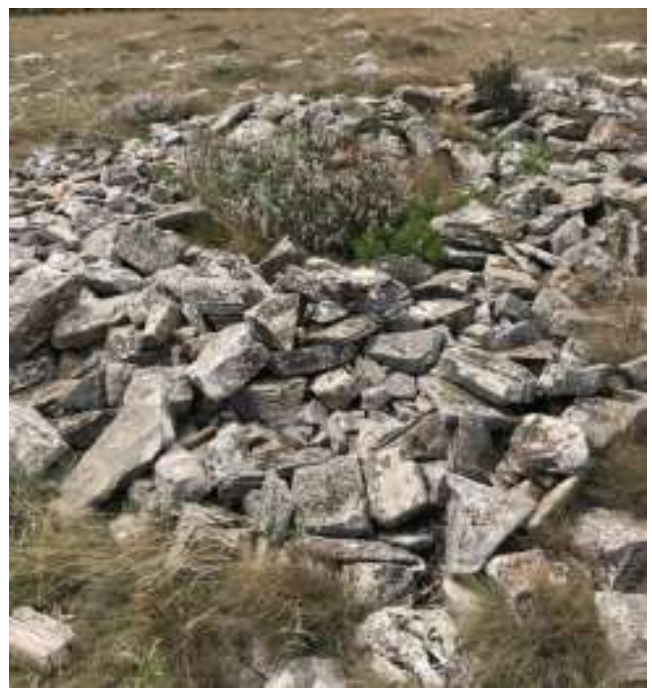

Kaynak: Refik Arıkan

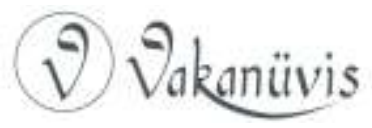


Ek 7: İsa Sofi Türbesi iç detay.

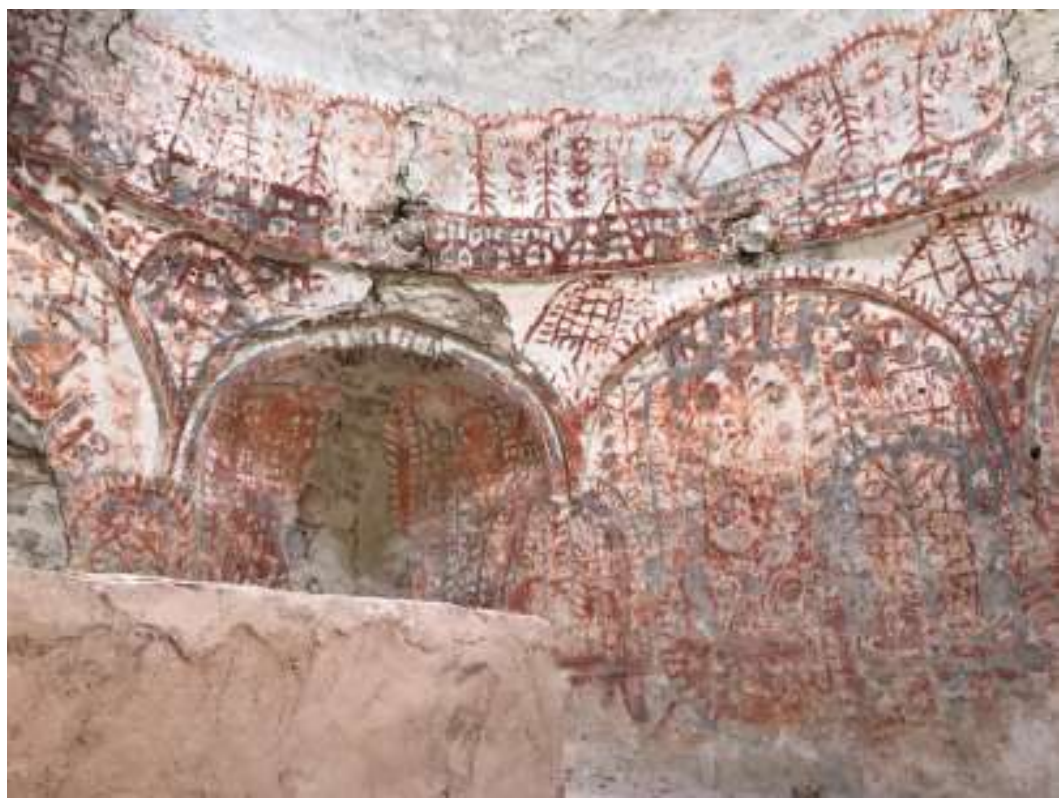

Kaynak: Nurfeddin Kahraman

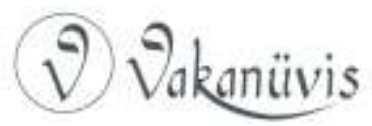

